2014

\title{
Eliza Haywood and the Narratological Tropes of Secret History
}

Rachel K. Carnell

Cleveland State University, r.carnell@csuohio.edu

Follow this and additional works at: https://engagedscholarship.csuohio.edu/cleng_facpub

Part of the Literature in English, British Isles Commons

How does access to this work benefit you? Let us know!

Publisher's Statement

First appeared in Journal of Early Modern Cultural Studies 14.4 (2014): 101-121. Printed by permission of the University of Pennsylvania Press.

\section{Recommended Citation}

Carnell, Rachel K., "Eliza Haywood and the Narratological Tropes of Secret History" (2014). English Faculty Publications. 47.

https://engagedscholarship.csuohio.edu/cleng_facpub/47

This Article is brought to you for free and open access by the English Department at EngagedScholarship@CSU. It has been accepted for inclusion in English Faculty Publications by an authorized administrator of EngagedScholarship@CSU. For more information, please contact library.es@csuohio.edu. 


\title{
Eliza Haywood and the Narratological Tropes of Secret History
}

\author{
RACHEL CARNELL
}

\begin{abstract}
A B S T R A C T
Eliza Haywood's novels and political writings are often considered in isolation from each other; however, there is a discursive thread that links her fictional and political works: her engagement with secret history. Across her career, in her novels as well as her political pamphlets and periodicals, Haywood deploys two important narratological tropes of the secret historian: the tendency to reveal the secrets of public figures while concealing the author's own political position and the tendency to muse self-reflexively about the author's own role as a writer of history. Haywood's facility in deploying these dual narratological devices of concealment and confession helps explain our difficulty in pinning down either her intrinsic political sympathies or her shifting partisan allegiances.
\end{abstract}

$\mathrm{I}^{\mathrm{n}}$ n 785 Clara Reeve divided Eliza Haywood's oeuvre into three parts: the "amorous novels" written "in her youth"; the "two books of the same kind as Mrs. Manley's capital work, all of which I hope are forgotten"; and finally, her "latter works," none of which "are destitute of merit" (I2O-2I). Although she inaugurated the now familiar binary distinction between "early" and "late" Haywood, Reeve nevertheless praised Haywood, three decades after her death, for her skills as a writer across various genres: the novelist of Betsy Thoughtless (175I), the periodical writer of The Female Spectator (1744-45), and the miscellaneous writer of The Invisible Spy (1754). In I8Io, in "On the Origin and Progress of Novel Writing," Anna Barbauld narrowed the lens through which subsequent generations would understand Haywood's works by emphasizing the distinction between her "earlier novels ... in the style of Mrs. Behn's" (i.e. "licentious") and "her later works" which Barbauld judges "by no means 
void of merit" (400-oI). Haywood had thus become by the early nineteenth century a marginalized novelist whose novels were valued in inverse proportion to their level of licentiousness.

By the time Ian Watt wrote his Rise of the Novel in 1957, Haywood would be lumped together with Behn and Manley as a writer of inferior novels, those exhibiting the tropes of "romance" rather than the Whig realism he located in what for him was the central thread of the "realist" novel's rise (I8-I9). In subsequent decades, many of us worked to reposition Haywood's works within the history of the novel, thus continuing a tendency to view her primarily as a novelist. ${ }^{\mathrm{I}}$ In her insightful new Political Biography of Eliza Haywood, Kathryn King shifts the critical conversation away from Haywood the novelist to Haywood the writer of political secret histories, plays, periodicals, and pamphlets. King teases out Haywood's shifting partisan alliances across her career, correcting the longstanding critical assumption that Haywood was a lifelong Tory. King also urges us to move beyond another critical truism: that of the binary opposition between "early" and "late" Haywood. King believes that "it will not be enough to construct new linear narratives" of Haywood's work; it "may be necessary to do away with linearity altogether" (195).

Although I agree with King's caution against seeking a single linear narrative to describe Haywood's work, I nevertheless propose that we may identify a consistent thread across Haywood's career, one that is noticeable in her less obviously political novels as well as in her more overtly political pamphlets and periodicals: her narratological engagement with the genre of secret history. In her analysis of Haywood's adroitness at political parody, Earla Wilputte cautions: "In our efforts to revise Haywood's role as a novelist, we must be careful not to neglect her other works where she also uses novelistic techniques and discourse" ("Parody" 230). We must likewise, I argue, consider the techniques of secret history in both her obviously political works and her novels.

Scholars have recognized Delarivier Manley's style of secret history in Haywood's two keyed secret histories from the 1720 s and in her Adventures of Eovaai (1736), but they have tended to overlook the traces of secret history in works that often appear to modern readers as apolitical works of fiction. ${ }^{2} \mathrm{Nev}$ ertheless, Haywood's engagement with secret history is evident both in works with "secret history" or "secret memoirs" on the title page, as well as in those marketed as pamphlets or novels. Across her career, Haywood deployed two important narratological tropes of the secret historian: the tendency to reveal the secrets of public figures while concealing the author's own political position 
and the tendency to muse self-reflectively about the author's own role as a writer of history in relationship to other writers of history. Moreover, Haywood's facility in deploying these dual narratological devices of concealment and confession helps explain our difficulty in pinning down either her intrinsic political sympathies or her shifting partisan allegiances.

\section{Secret History and Narratological Self-Consciousness}

The secret history was a genre of oppositional political propaganda made popular in England and France following late seventeenth-century French (1669) and English (1674) translations of Procopius's Anekdota, an initially unpublished collection of salacious anecdotes about Emperor Justinian in which Procopius self-consciously undermines his own official (and hagiographic) histories of Justinian's reign. ${ }^{3}$ Although the seventeenth-century translations of Procopius were not the first tell-all insider account of court secrets in earlymodern Europe, the translations of his work struck a chord in late seventeenthand eighteenth-century England and France, as Rebecca Bullard explains (35-38). At the height of the Exclusion Crisis the English translation of Anekdota was reissued with the provocative title The Debaucht Court. Or, the Lives of the Emperor Justinian, and His Empress Theodora the Comedian (1682), encouraging readers to identify similarities between the courts of Justinian and Charles II and encouraging Exclusionist propaganda writers to write similar accounts of their own time. Moreover, these works follow Procopius in their authors' self-consciousness about their "own claims to disclose intelligence" (Bullard 2I).

The Perplex'd Prince ( 1682 ) is a romantic secret history in which Charles II (Conradus) is shown to have been secretly married to Lucy Walter (Lucilious) before their son, the Duke of Monmouth (Heclacious), was born. In his dedication to the Exclusionist Lord Russell, the author T. S. (possibly Thomas Shadwell) describes the difficulty of the "present times" in which the public is "Pestered with nothing but Invective Libels and Scurilous Pamphlets, most of which are either cunningly designed to invalidate the Truth of a real Plot, or to insinuate and prove a fictitious one" (sig. A2r-v). In response, the author of The Fugitive Statesman, in Requital for The Perplex'd Prince (1683) begins with a reference to "Spleen and Hatred" that "the Faction" demonstrates to the government, most particularly in "the Business of the Black Box" produced by the "Libel, call'd the Perplex'd Prince" (sig. A3r-v, italics reversed). This prefatory give-and-take illustrates the narratological self-consciousness that Bullard 
finds central to the structure of secret history. During William and Mary's reign, Whig secret historians self-consciously aligned the values of openness and transparency with Revolution principles and a Whig version of history. In the preface to his True Secret History of the Lives and Reigns of all the Kings and Queens of England (1702) the Whig politician John Somers describes his source as a spy in the French court who took "Minutes of the most Secret Transactions" (sig. $\mathrm{A}_{3 \mathrm{v}}$ ), thus affirming "the veracity of the evidence he presents in his own secret history and, by extension, the authority of his own interpretation" (Bullard 6I).

During Queen Anne's reign, Delarivier Manley made popular a form of keyed secret "memoir" with romantic pseudonyms for real-life courtiers and public figures. Many subsequent eighteenth-century works enticed readers with the tag "secret"; Eve Tavor Bannet observes that between 1690 and 1750, "over eighty different works including 'Secret History' in their titles appeared ... and even more works used the descriptor in their sub-titles" (368). Twentieth-century scholars nevertheless tended to relegate secret histories to "the wrong side of opposition between truth and scandal, fact and fiction" and recast any secret history "considered worthy of serious attention," as "a political memoir, a novel, political journalism, or eye-witness history" (Bannet 367 ). The genre of the secret history, however, would have been extremely familiar to early eighteenth-century writers such as Eliza Haywood.

In considering the difference between those texts that Haywood labeled as "secret histories" and those she described as "novels" on title pages, George Whicher suggested a century ago that in her earliest works Haywood "attached no particular significance to her use of the term [secret history], but employed it as a means of stimulating meretricious interest in her stories" (92). Early in her career, however, as Bullard observes (165), Haywood indicated her appreciation of the marketability of the category of secret history by reissuing The Works of Mrs. Eliza Haywood; Consisting of Novels, Letters, Poems, and Plays (1725) with the new less classical title Secret histories, Novels and poems... by Mrs. Eliza Haywood (1726).

In works from the 1720 s Haywood sometimes used both "secret history" and "novel" on the same title page-as in The British Recluse: or, the Secret History of Cleomira, Suppos'd Dead. A Novel (1722) - suggesting that what Haywood meant by "novel" at this time was shaped by the French word nouvelle, meaning a piece of news or gossip, possibly about a real person. For example, Sébastien Brémond's keyed secret history about Charles II and the Duchess of 
Cleveland, Hattigé: ou, les Amours du Roy Tamaran. Nouvelle (1676), was translated into English (without keys) as Hattige, or the Amours of the King of Tamaran. A Novel (1680). ${ }^{4}$ As Lennard Davis has observed, there was not always a fine distinction made between fact and fiction in relating what was "novel" or "news" in the early eighteenth century (5I). Kate Loveman has examined reading practices during this era, noting that readers read actively, looking for real persons and political allegory even in works that modern readers might presume were fiction (3-8); thus, whether or not a work was labeled "novel" or "secret history," readers were likely to look for real persons behind the characters.

In the preface to The Injur'd Husband; or, the Mistaken Resentment. A Novel (1722), a story involving adultery, murder, and suicide, Haywood reflects on the reading practices of her era when she defends herself against an anticipated "Accusation" that in this story about a French baroness, she is actually attempting to "expose the Reputation of an English Woman of Quality" (sig. A4r, italics reversed). Although the work does not appear to be overtly political, in dedicating the work to "Lady How" (i.e., Viscountess Charlotte Howe), Haywood appears to be currying favor with a courtier well connected to the Hanoverian royal family, complimenting Howe as a model of virtue in contrast to her heroine's lack of virtue. In the preface to The Fair Hebrew: or, a True, but Secret History of Two Jewish Ladies, Who Lately Resided in London (1729), Haywood reflects on the difference between publications about real events and "so many Things, merely the Effect of Invention, which have been published, of late, as SECRET HISTORIES" (sig. AIr). She claims that she includes no incident that was not told to her by a "Person nearly concerned in the Family" (sig. AIr). Haywood calls attention to the truth claim of the secret historian here, but offers no direct clue to her political intent.

Four years earlier, however, Haywood sounded like a more openly partisan secret historian in Mary Stuart, Queen of the Scots: Being the Secret History of her Life (1725), a translation of Pierre le Pesant de Boisguilbert's Marie Stuart, Reyne d'Escosse. Nouvelle Historique (1674), a work that appears to be in conversation with earlier Exclusionist secret histories. Although Boisguilbert uses the tag "nouvelle historique," Haywood's subtitle Secret History, rather than bistorical novel, indicates that she recognizes it as part of the tradition of secret history. Moreover, Haywood's translation of the preface is faithful to the original, retaining Boisguilbert's self-consciousness about the act of writing history from a particular political position; this work claims a narratological middle 
ground between the extremes of "Father CAUSSIN's bigoted zeal" and "the malicious DETRACTION of Buchanan" (iii). Haywood's narrator may claim neutrality, but this "True History," as she describes her account, is clearly a corrective to anti-Stuart versions of history. Moreover, Haywood's phrase "True History" is a relatively literal translation of the phrase "Histoire tres veritable" in Boisguilbert's preface (3).5 James Freebairn, by contrast, uses the term "Historical Novel" (vii) in his rendering of the same sentence in the Author's Preface to his own English translation of Boisguilbert's work, which appeared in the same year as Haywood's. Freebairn titles his translation simply The Life of Mary Stewart, Queen of Scotland and France, de-emphasizing the original work's connection to the other secret histories with which it was in conversation in the $1670 \mathrm{~s}^{6}$

In contrast to Boisguilbert's 1674 work, in his True Secret History of the Lives and Reigns of all the Kings and Queens of England (1702), John Somers casts doubts on the legitimacy of the whole Stuart line of monarchs descended from Mary Stuart by citing "one of his [James I's] Contemporaries" (290): "I cannot in the best stories I have read, find clearly who was King James's father" (297). This unnamed source describes Mary at the time of her marriage to Darnley as a "lusty young widow" and offers various suggestions as to who might be the actual father of the Stuart line of monarchs, including an "Italian Fiddler" and "a Scotch Lord" (Somers 297). Haywood's translation of Boisguilbert demonstrates that the Queen was not "criminal" or adulterous (23), but that others were spreading rumors to this effect; Haywood insists that Mary married Lord Darnley for "LOVE" (64). Although the couple did not remain long in love, Haywood, following Boisguilbert, does not challenge the legitimacy of the son, James VI, but emphasizes his royal connections in describing how Mary was "brought to bed of a Son whose God-father was the King of France and his god-mother ELIZABETH, Queen of England" (85).

Haywood's translation, in contrast to other anti-Stuart biographies of Mary Stuart, paints a sympathetic portrait of the Scottish monarch, suggesting how "any disinterested Person" should "judge the Afflictions of that distressed Queen" (193), who "deserved a better Fate than by dying by the hand of a common Hangman" (240). The final lines of Haywood's translation, closely following Boisguilbert's original, underscore Boisguilbert's and Haywood's understanding of how mainstream historians dismantle other counternarratives of history: "her Servants put up an Epitaph for her; which was soon taken down because it spoke so much in her praise, and set for the Cruelty of 
those who put her to death" (240). This translation, published in the same year as Haywood's first keyed secret history, a work that Kathryn King suggests was written to curry favor with the Whig government, is not necessarily a work of pro-Stuart propaganda. Haywood's translation of Boisguilbert nevertheless demonstrates Haywood's familiarity with the narratological tropes of secret histories as well as her willingness to deploy these tropes to voice skepticism towards anti-Stuart narratives of history.

\section{Politics and Love in Excess}

Half a decade before translating Boisguilbert, Haywood wrote the best-selling Love in Excess, or the Fatal Inquiry (1719-20), which is described as a "novel" on the title page. Following Ros Ballaster's lead in Seductive Forms, most scholars have viewed it as an apolitical work of "amatory fiction," although Toni Bowers identifies in it certain motifs of post-1688 Toryism. Kathryn King has now identified the publisher of the work, William Chetwood, as "an author and bookseller of decidedly Whiggish stripe" (25); Chetwood was also one of the booksellers listed for The Injur'd Husband, which four years later Haywood would dedicate to the well-connected Hanoverian Lady Howe. Although King does not offer a detailed political interpretation of either of these novels in her biography of Haywood, it is probably significant that Chetwood dedicated Love in Excess to Anne Oldfield, an actress who had liaisons with two prominent Whig politicians: the first was Arthur Maynwaring (1668-I7I2), the Whig M.P. who had served as a self-styled political secretary to the Duchess of Marlborough during the last years of Anne's reign; the second was General Charles Churchill (1678-1745), an illegitimate nephew of Marlborough who had served in the British army under his uncle's command. Although Chetwood, rather than Haywood herself, signed the dedicatory preface, the choice to dedicate this to such a well-connected Whig actress was strategic for a writer who had begun her career on stage and who would have hoped to benefit from the patronage of someone as well connected as Oldfield?

Love in Excess is set at the end of "the late war between the French and confederate armies" (37), that is to say, the War of Spanish Succession, in which the Duke of Marlborough was captain general and commander of the Allied forces fighting to defeat the French. Marlborough's brother Charles Churchill and the latter's illegitimate son Charles Churchill (who lived openly with his mistress Anne Oldfield, the dedicatee of the work) also led battalions in the major campaigns. Haywood's heroes, Count D'Elmont and his brother 
Brillian, are Frenchmen, who served on the other side in the same war and "had acquired a more than ordinary reputation under the command of the great and intrepid Luxembourgh" (37). In explaining why D'Elmont marries Alovisa, Haywood observes, "Ambition was certainly the reigning passion in his soul, and Alovisa's quality and vast possessions" promised him "a full gratification of that" (76). If we are to read as many readers of the time would have done, looking for allusions to real persons and real events, we may well conclude that Haywood was following Aphra Behn's lead in Love Letters Between a Nobleman and his Sister (1684-87), in which France represents England. We might also then assume that, as in Behn's Love Letters and Manley's New Atalantis, "Ambition" is an undesirable trait associated with Whigs after the Revolution of $1688-89$.

Viewing this novel as critical of (Whiggish) ambition is compatible with Toni Bowers's recent analysis of the novel in terms of "collusive resistance," a motif representing the situation faced by Tories who were obliged to cooperate with the government after $1688{ }^{8}$ How then do we explain the dedication to the Whig Anne Oldfield? The ambitious brothers who return to domestic life at the end of the War of Spanish Succession may, at some level, represent John, Duke of Marlborough, and his brother Charles Churchill. Marlborough was nominally a Tory, even though he regularly cooperated with the Whig Junto to persuade enough Whigs in Parliament to continue voting to fund the increasingly unpopular War of Spanish Succession. Setting Love in Excess at the end of that war situates it at the time when public outcry against Marlborough was at its height. Just before Anne dismissed him from office in I7II, Marlborough was accused by Tories in Parliament of peculation and of profiting personally from the war; he chose to leave England for a self-enforced exile on the Continent from I7I2 to I7I4, and he was politically rehabilitated only with the accession of George I.

Like Manley, Haywood was certainly criticizing the selfish "Ambition" of those who profited personally from the war. D'Elmont, however, does not remain a Whig caricature of ambition throughout the entire novel. At the beginning of the third part, Haywood alerts us to her protagonist's evolution: "Ambition, once his darling passion, was now wholly extinguished in him by these misfortunes" (163). D'Elmont is cured of this character flaw following Alovisa's death, as evidenced by his more sincere and durable love for Melliora. In partisan allegorical terms, Haywood appears to rehabilitate a Whig character by showing his more traditional chivalric impulses: in the third part he in- 
tervenes, as a responsible (Tory?) hero, to save someone outnumbered in a fight; in the final volume of the novel, he consistently resists the temptations of other women who continue to offer themselves to him. Haywood may be complimenting those officers, including Marlborough and his brother and nephew, who fought in the War of Spanish Succession and were rehabilitated politically after I7I4; at the same time, her narrator coyly expresses skepticism about Whigs who display the traits of ambition.

Haywood's first novel thus suggests that she may have held some natural Tory sympathy, also evident in her subsequent decision to translate Boisguilbert's Marie Stuart. Nevertheless, even in her first published work, Haywood demonstrates the narratological dexterity of a pragmatic secret historian by offering a Tory denunciation of Whig ambition even while currying favor with potential Whig patrons during the reign of George I. Although her narrator offers few passages in which she waxes as self-reflectively about other biased narratives of history as she does in her translation of Marie Stuart, Haywood nevertheless ends the novel with a reference to a change in the tone of gossip about her hero: "those who in the Count's absence had taken a liberty of censuring and condemning his actions, awed by his presence, and in time won by his virtues, now swell his praises with equal vehemence" (266). Her narrator thus suggests how rumor and history are re-narrated with every change of regime.

\section{Haywood's First Keyed Secret Histories}

Although Haywood was clearly versed in the tropes of late seventeenthcentury secret histories, the best-known secret histories in her own youth would probably have been Delarivier Manley's Secret Memoirs and Manners... from the New Atalantis (1709) and Memoirs of Europe (I7IO), works that saw multiple initial printings and were reissued together in 1716 and 1720 , at the time that Haywood was beginning her career as a writer. In contrast to the more self-conscious narration of late seventeenth-century Exclusionist and Whig secret histories, Manley's style is one of narratological concealment. Most of The New Atalantis, which appeared with no author's name on the title page, is not narrated directly by an implied author but by the allegorical figures Intelligence and Fame, who recount court and society gossip to Astrea and Virtue. In the first volume of The New Atalantis, the narrators rarely address the reader directly. Manley's voice comes through in her dedication to the Duke of Beaufort, a Jacobite peer, but she would not have been certain of his 
backing at the time that she wrote the dedication, and she does not reveal much of her own personality in it. By contrast, in the dedication to the second volume, she confidently describes herself as "like a Hero who has gain'd an almost impossible Victory," and she looks back "with Wonder at my own Ambition" (2:151, italics reversed).

Because Haywood's two keyed secret histories borrow Manley's basic structure of embedded narrators recounting gossip, scholars have often viewed Memoirs of a Certain Island Adjacent to the Kingdom of Utopia (1724, 1725) and The Secret History of the Present Intrigues of the Court of Caramania (1727) as Tory secret histories. ${ }^{9}$ However, as King points out, in 1725 Haywood, who had broken with Aaron Hill's circle, may have been seeking patronage by staking out a pro-government position (32). In other words, like Manley in the first volume of The New Atalantis, Haywood may have been writing her keyed secret histories without certainty about the works' reception. Manley at least appears to have hoped her own work would be appreciated by the Duke of Beaufort. Haywood did not dedicate either of her keyed secret histories to a potential patron; her authorial position is thus even more narratologically concealed than Manley's.

Although Haywood's two keyed secret histories mock some of the same characters, including the Marlboroughs, that Manley had satirized in The New Atalantis, by 1725 criticism of the Marlboroughs no longer indicated a Tory bias or even an oppositional bent to Walpole's government. The Duke of Marlborough was dead; James Craggs, who had risen in power through the Marlboroughs' influence, had committed suicide after converting government debt into South Sea stock. As Bullard explains, by making Craggs, as Lucitario, "the necromancer who governs the Enchanted Well" and hence "the architect of the Bubble," Haywood colludes with "the ministerial cover-up operation orchestrated by Robert Walpole" (166). Kathryn King explains that Haywood's apparent support of Walpole's ministry at this time is not surprising, given that in the 1720 s "Walpole was courted by writers who would go on to become leading names in the Opposition" (38). Haywood's mockery of the Whig Dowager Duchess of Marlborough, who appears as in the second volume as the "designing, proud, cruel, and revengeful" Marama (2:249), makes sense when we consider the Duchess's strained relationship with Walpole. As a modern biographer explains, "Still unable to forget that he had once been her husband's clerk, she [the Dowager Duchess] was ready to bridle at any change in his demeanour to her now that he was prime minister" (Harris 266). Haywood's por- 
trait of the Duchess of Marlborough lends support to the theory that she was "writing in the hope or expectation of reward from the ministry" (Bullard I68), even though she offers no dedication to anyone at court.

Marta Kvande observes that Haywood's actively political narrators often "take up the position of outsiders whose apparently disinterested position endows them with virtue and makes them uniquely qualified to offer criticisms" (626). For Kvande, Cupid serves as a virtuous outsider who disparages Walpole's government in Memoirs of a Certain Island. King's and Bullard's analyses suggest that Haywood was not writing against Walpole at this time, yet, as Bullard observes, Haywood was still writing from a position of outsider: “While Manley's New Atalantis is principally concerned with figures of some public standing, Haywood makes no claims to reveal secrets of state or even recount well-known scandalous political intrigues in any detail” (170). This would also explain why Haywood's keyed secret histories lack not only dedications and prefaces that might indicate her own authorial position; they also notably lack passages in which the narrator reflects self-consciously on the act of writing history.

The absence of narratological self-reflection stands in stark contrast to the profusion of such moments in Haywood's translation of Boisguilbert's Marie Stuart, published in July 1725, the summer after the appearance of the first volume of Memoirs of a Certain Island, published in September 1724, and a few months before the publication of the second volume of Memoirs, which appeared in October 1725. This narratological reticence in Memoirs of a Certain Island may stem from Haywood's position in 1725 as political outsider, no longer part of the Hillarian circle and seeking patronage elsewhere. Haywood does not reflect self-consciously on her decision to court favor with Walpole's government in the way that she follows Boisguilbert in openly expressing concern about anti-Stuart narratives of history in her translation of Marie Stuart. Whether or not Haywood was intrinsically a Jacobite sympathizer (because of personal or family connections as yet undiscovered by biographers), her most self-reflective narratological moments, in works from her 1725 Mary Stuart to her 1753 The History of Jemmy and Jenny Jessamy, express what appears to be a genuine skepticism about anti-Stuart narratives of history. Of course, these moments of narratological openness are countered by the narratological structure of many other works in which it is difficult to pin down her narrator's political position. 


\section{Mockery of Tory Alderman and Printer John Barber}

In another text from the mid-I72os that links Haywood to Manley, Haywood's own narratological and ideological position is also veiled. The British Library catalogue suggests that The City Jilt; or, the Alderman turn'd Beau: A Secret History (1726) is an account of John Barber, the Tory printer elected Alderman in 1722 - the same Tory printer who printed most of Delarivier Manley's works after 1708 and in whose printing house Manley lived from about 1709 until her death in 1724 . One clue that Haywood may have been mocking Barber is that the work was printed by John Roberts, a trade publisher often used by Edmund Curll, who later wrote an unflattering posthumous biography of Barber; Curll himself used Roberts as a trade publisher for Manley's The Adventures of Rivella. ${ }^{10}$ There is, however, neither a preface nor a dedication to this work to offer us a clue to Haywood's personal views of Barber.

Barber, who began life as a printer's apprentice, made a substantial fortune by cultivating Tory contacts and gaining government printing contracts during Anne's reign; subsequently, he profited in the South Sea Bubble (likely benefitting from insider information gleaned from printing documents for the venture). According to one biography published just after Barber's death in I74I, Barber had been something of a womanizer who had aged prematurely and was suffering from gout by the time he was forty (Life and Character of John Barber 3I-32). This same generally flattering account of Barber's life suggests that Manley ceased being Barber's “domestic Favourite," sometime after I7I4 and was replaced in Barber's affections by Sarah Duffkin, a former maid servant to Manley who proved herself "an excellent Manager of his Affairs" and was "just to him to the last Hour of his Life" (26). Edmund Curll, in his counter narrative, An Impartial History of the Life, Character, Amours, Travels, and Transactions of Mr. John Barber, also published in I74I, puts these same details in a less flattering light, suggesting that in settling down with Duffkin in high style, Barber broke Delarivier Manley's heart: "such was the Insolence of his Behavior to her [Manley] that she justly gave him the name of Tyrant, and in a few years he might be said to assume the Brute, in forsaking the Polite-Mistress to take up with the ignorant serving Wench" (44).

Haywood's mocking account in The City Jilt, if the work is intended as a secret history of Barber, may have to do with rumors of his reputed treatment of Manley, who had died two years earlier, even though Manley herself never publically complained of his treatment of her. ${ }^{\text {II }}$ Haywood may also have intended some political mockery of Barber, who traveled to Naples in I722, 
reputedly with thousands of pounds in promissory notes for the Jacobite cause. Haywood, of course, appears to have harbored some sympathy for the Jacobites, but she still may have found reason to mock the manner in which Barber delivered his support to that cause. Barber's sympathetic biographer refers to "idle Reports" about an "Exchange of Civilities" between Barber and the "Chevalier de St. George" (James Francis Edward Stuart), although this biographer suggests that "if he had any share in the Intercourse talk' $d$ of; he had behaved in Manner, which had placed a Discovery out of the Reach of his Enemies; and shew'd a Policy superior to their Watchfulness and Cunning" (Life and Character 45). If Haywood is describing Barber in the portrait of her Alderman Grubguard, she does not depict this level of cunning in her character. Instead, she emphasizes the Alderman's trustworthiness by having him assure Glicera, "No, I will not cheat you" (52), even as the latter is planning to cheat him and use his money to extract revenge on a previously unfaithful suitor.

Haywood's Alderman may resemble the real Barber, whose complimentary biographer describes him as "grateful and just to his Friends" (36). Since Haywood's narrator never reveals her own thoughts to her readers, we are left without knowing whether Haywood means the reader to admire Alderman Grubguard for his loyalty and generosity to her heroine (and, by extension, to the Jacobite cause) even as we laugh at him for his foppery and his gullibility. Haywood was probably cautious about offering a preface that would have called attention too directly to her parody of Barber, who was still an important figure in the printing trade in the mid-I720s as well as someone whose politics the Whig government distrusted. Nevertheless, she appears to have been gently mocking the Tory printer at a time when she was seeking Whig patronage, even as she was also acknowledging the generosity and steadfastness of the man with whom Delarivier Manley lived during the most stable and successful years of her professional life. Functioning analogically, this secret history obscures rather than reveals the author's precise political position. It also obscures as much as it reveals about Haywood's attitude towards the Tory Delarivier Manley and her publisher.

\section{Disguise and Self-Consciousness in Haywood's Later Works}

In The Adventures of Eovaai, Princess of Ijaveo. A Pre-Adamitical History (1736), her next keyed secret history after Memoirs of a Certain Island and Secret History ... of the Court of Caramania, Haywood again borrows the structure of Manley's earlier secret histories, deploying layers of translators and commen- 
tators. As Ros Ballaster has pointed out, the "complex narrative frame ... allows her to pass comment on the opposition positions rehearsed, but not necessarily endorsed, in the narrative" ("A Gender of Opposition" 157). Ballaster assumes that Haywood's dedication to the Dowager Duchess of Marlborough should be read as satirical since she had previously satirized her in Memoirs of a Certain Island. In the I730s, however, especially during the general election of 1734 , the Duchess of Marlborough was exceedingly active in her support of the opposition. According to a modern biographer, Marlborough was "Courted, flattered, and consulted by their leaders, both peers and commoners, and even by the Pretender himself" (Harris 299); she was almost prepared to support as M.P. for Windsor Lord Masham, the son of her cousin and rival for Queen Anne's affection, Abigail Masham (299-300).

Just as Manley had acknowledged in 1709 a range of Tory and Jacobite positions in her New Atalantis-from that of the moderate Tory Robert Harley to that of the acknowledged Jacobite Henry, Duke of Beaufort-so it would have been a good political strategy for Haywood in the I730s to dedicate her work to someone who was in the thick of opposition politicking against Walpole. Kathryn King suggests that the different political positions to which the heroine of Eovaai is attracted represent "a Bolingbrokean marriage of Tory monarchical ideals and Whig skepticism about the supposed majesty of kings" (89). Haywood may also, like the Duchess of Marlborough in the 1734 elections, simply have been courting all possible opposition factions in Eovaai.

Almost a decade later, during the prelude to the Jacobite Rising of 1745 , Haywood published a work that is often read as an apolitical novel but which has the narratological and political self-consciousness of a secret history. In the preface to The Fortunate Foundlings (I744), Haywood echoes her comments in the preface to The Fair Hebrew about the many works of "Invention" masquerading as truth in the guise of secret history: "The many Fictions which lately have been imposed upon the World, under the specious titles of Secret Histories, Memoirs, \&c. \&c. have but given too much room to question the Veracity of every Thing that has the least Tendency that way" (sig. Air). She insists that The Fortunate Foundlings is based on "Original Letters, Private Memorandums" (sig. Arr), unlike other works that merely claim to be true. Moreover, the subtitle indicates that the novel may be revealing "secrets" about some grandchildren of the late duke of Rutland: "Being the Genuine History of Colonel M—rs and his Sister, Madame du Pl—sy, the Issue of the late $\mathrm{Ch}$ —es $\mathrm{M} \longrightarrow \mathrm{rs}$, Son of the late Duke of $\mathrm{R}-\mathrm{l} \longrightarrow n d$." The blanks in the subtitle also suggest the style of earlier political secret histories. 
Genealogical research, however, does not identify such persons as actual descendants of this duke. ${ }^{\mathrm{I2}}$ In fact, The Fortunate Foundlings seems to function less as a keyed secret history than as a broader political allegory to which readers are made alert by its setting in the "the ever memorable year I688" (Fortunate Foundlings I). As Earla Wilputte suggests, the voyages that the female foundling takes on foot across Europe may represent the voyages of either Charles Edward Stuart or Charles XII of Sweden ("Room to Fable" 42). As I have argued elsewhere, the title page of this novel appears to offer a specific allusion to a particular (Whig) family as cover to an allegorical Jacobite novel (Partisan Politics 150-52). Carol Stewart has identified further markers of Jacobite ideology in the work, suggesting that Dorilaus, the foundling's father, should be read as a figure for James II (58). Teasing the reader with both analogical and allegorical political clues, Haywood deploys a trope familiar from secret histories: simultaneous revelation and disguise.

Two years later in The Parrot, a periodical commenting on the plight of the Jacobite military leaders in the summer of 1746 , Haywood's parrot narrator begins by showing his appreciation the current monarch (George II): "We have a Sovereign who centers all of his Wishes in the Peace, Opulence, and Glory of his Subjects; who loves us as his Children, and who is so far from encroaching on our Rights that he is the best Guardian of our Laws and Liberties" (sig. A5r-v) Here, the parrot sounds like John Somers in the preface to his True Secret History, in which he praises the transparency of Anne's reign over the "Arbitrary government of the late King [James II]" (sig. A2v). The parrot refers to George II in exaggerated terms: "we, in return, revere him as a Father and almost adore him as a God" (sig. A5v). In contrast to Somers, whose narrator appears genuinely to be celebrating the Revolution of I688-89, Haywood's parrot quickly undercuts the apparent perfection he has just described by suggesting that there is cause for large-scale grievance when the parrot insists that he "shall never report Grievances, till they are generally complained of" (sig. A5v). Moreover, such grievances are unlikely as long as "his present Majesty, or any of his truly royal and magnanimous Issue remain" (sig. A5v), a statement blatantly contradicted by the complaints made in the attached "Compendium of the Times" about the harsh punishments of the Jacobite rebels.

The ostensibly satisfied narrator of the main part of the periodical blithely continues, after having assured us of his contentment with the Hanoverian succession: "yet as what has been, may again be, and it is impossible that the most sanguine should answer for Futurity, it is good to have a Remedy at Hand 
in all Events" (sig. A5v). Is the parrot suggesting that he acknowledges the possibility of a return of the Stuart monarchy that "bas been" and "may again be"? He concludes by suggesting that any "Disturbances I may sometimes Create, are more than attoned [sic] for by my Power of doing Service, if ever Occasion should demand it" (sig. A5v). This implicit offer to serve echoes Horatio's pledge to the Chevalier St. George in The Fortunate Foundlings: "if a day should come when you, sir, shall attempt the prize, how fortunate would it be for me to have learned to serve you as I am obliged by much more than my duty, by the most natural and inviolable attachment of my heart" (130). Moreover, the "friend in the country" who pens a "Compendium of the Times" at the end of each issue of The Parrot seems confident that readers will feel the same sympathy that this "friend" does for the plight of the fiancée of the executed Jacobite James Dawson-even if this fiancée is "entirely fictitious," as King points out (I46).

Responding to those of us who have identified Jacobite sympathy in this work, ${ }^{13}$ Kathryn King argues that this periodical does not appear to have been aligned with other known Jacobite networks: it offers "no call for a return to the rightful monarchy" (I48). On the other hand, the parrot offers a clear sense of comradeship with those who are sympathetic to the Stuart cause in the abstract: although they may not be interested in funding it or fighting for it, they are not opposed to a Stuart restoration one day coming to pass. This position in 1746 could be the natural evolution of Haywood's position vis-à-vis the shifting political landscape in the 1740 s. In 1744, the plotline of The Fortunate Foundlings may have represented a coy nudge to those Jacobites accustomed merely to raising a toast to the King over the Water rather than taking up arms: Horatio, who valiantly pledges loyalty to James Edward Stuart in 1708, appears more heroic than his father who left London in 1688 to avoid getting involved in political conflict. ${ }^{14}$ In the wake of the failed Rising of ${ }_{1745}$, however, Haywood may feel that all she dares express is sympathy for those being punished as traitors and a vague hope of being useful as a writer again in some future time. Haywood's parrot narrator expresses skepticism about anti-Jacobite narratives of history, even as he claims to voice support for the government. This covert double-voicing helps explain why critics continue to puzzle over the degree of Jacobitism Haywood was expressing in this periodical.

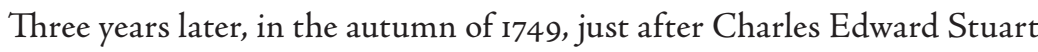
clandestinely visited London and was received in the Church of England, Haywood brought out $A$ Letter from $H-G-g$... to a Particular Friend, in which she may have been trying to reignite interest in the Jacobite cause. Her 
narrator offers a more cautious tone than that used by her parrot: rather than assuming that the reader will naturally feel the "sympathy" her parrot expresses for the cause of the Jacobite rebels, here the narrator suggests, in more neutral language, that $\mathrm{s} /$ he is publishing this found manuscript merely to "satisfy the Curiosity of the Town," which s/he observes has been "raised pretty high on account of that adventrous Wanderer" (iii). This hagiographic account of Charles Edward Stuart as romance hero is rendered in a light tone. Since her narrator is ostensibly an attendant to Charles Edward Stuart, and thus biased in his favor, it is even more difficult to pin down Haywood's own political motives in this work. Yet, the government officials who arrested Haywood seem to have taken A Letter seriously enough to have interrogated her about it. As King suggests, the idealized portrait of Charles Edward Stuart might have been in fact a "pro-Frederick portrait of Charles" (185) as part of the Leicester House campaign.

The work might also have been intended as a coy piece of advice to Stuart himself: now that he has been received in the Church of England, he should start acting the part of royal hero if he wants to make any future attempt on the throne. Or the work may have been marketed in such a way as to appeal to "a multiple reading public's political allegiances and consumer desires" (Ingrassia I24). As Wilputte has pointed out, Haywood's narrator is focused as much on what cannot be known about Charles Edward Stuart as what can be known, and her romantic depiction of him seems exaggerated to the point of parody, demonstrating "that Charles was, finally, a fictional construct who did not exist in the real world" (215). Wilputte suggests that Haywood ultimately demonstrates that "readers-Jacobites, non-Jacobites, journalists, and the government-for whatever their own agenda, deliberately create their own fairy-tale from formulaic remnants, not reality" ("Parody" 215). Thus, the most significant narratological feature of the work seems to be its self-consciousness about the act of historical myth-making.

Haywood's oft-expressed sympathy for the Stuart cause is voiced less often from the position of a political activist and more often from that of a secret historian concerned about how the Stuart cause would be represented to posterity. In her final novel, The History of Jemmy and Jenny Jessamy (1753), a work that few scholars have examined for its political overtones, Haywood's narrator interrupts the story, offering meta-commentary on the bias of other historians. ${ }^{15}$ In that novel, whose hero borrows a name from Jacobite ballads, Haywood's narrator condemns "some political historians of modern date, [who] attempt to mislead" the public (2:197). She seems bothered in particular 
by these contemporary anti-Jacobite versions of political history in which the writers refer to "the person on whom fortune has not vouchsafed to smile [presumably Charles Edward Stuart] ... [and] will not allow [him] . . any one virtue or good quality" (2:197). In this brief, but seemingly heartfelt, narratological intervention in a long novel about a hero named Jemmy, Haywood again reveals her concern, evident in her early-career translation of Boisguilbert, about the way that Whig bias shapes standard narratives of history.

Three years later in The Invisible Spy (1754), one of her final works, Haywood insists on the unknowability of her narrator. While she recognizes that some may see her as "a philosopher . . . a fool . . . a stoic . . . a man of pleasure ... a courtier ... [or] a patriot" (I), she seems to revel in her readers not being able to discover her true identity: "whether I am any one of these, or whether I am even a man or a woman, they will find it, after all their conjectures, as difficult to discover as the longitude" (2). Haywood not only takes pride in her narrator's identity being difficult to pin down, but she actively discourages her readers from seeking any more information. Haywood emphasizes that she will be the one who decides when she will reveal anything about her narrator's real self and sympathies. The author, like other secret historians before her, emphasizes her power to divulge or conceal secrets at her own discretion. But this is hardly a new narratological position for Haywood. From the start of her career, she understood that narrating history is necessarily a political act, and she demonstrated the talent of a secret historian in self-consciously suggesting and concealing her own political sympathies.

\section{NOTES}

I. Two decades ago, Bowers challenged the traditional tendency to devalue amatory novels by women ("Sex, Lies, and Invisibility" 74). Considering the ways in which Haywood was then presumed to be copying, rather than being copied by, writers such as Samuel Richardson and Henry Fielding, Backscheider observed a decade and a half ago: "No wonder the story of the novel is in disarray" (IO2). As I suggested in a subsequent monograph on the partisan history of narrative realism, we might understand Haywood as writing Tory or Jacobite "realism" in opposition to others writing more Whiggish forms of realism (Partisan Politics 43).

2. According to Annabel Patterson, two styles of secret history were common in the late seventeenth and early eighteenth centuries ( $183-84)$. The first used the names of actual persons and referred to real events as does as Andrew Marvell's An Account of the Growth of Popery and Arbitrary Government (1677). The second style used pseudonyms to lightly disguise the court and society figures they mocked; these works were sold without keys in the first edition but keys were often sold or circulated separately and included in subsequent published editions. I refer to Haywood's Memoirs of a Certain Island and Secret History 
of ... Caramania as "keyed" because they are designed to be read with a key to decode the persons behind the pseudonyms; her Marie Stuart, by contrast, is not keyed but instead uses the real names of all the historical figures involved. I avoid the term roman à clef for the keyed works (although Patterson and others use it) because it suggests misleadingly that these works were novels; the term is also anachronistic since it was not used in English until the nineteenth century (according to the OED).

3. See Patterson (I83) and Rebecca Bullard (38).

4. Sébastien Brémond is often incorrectly identified as Gabriel de Brémond (see Grobe); René Godenne mentions the French keys (xi).

5. These words appear in the original French without the usual accent marks.

6. Rivka Swenson's paper on this work at ASECS 2014 called my attention to Haywood's sources. Swenson also generously shared a working draft of her essay "History," forthcoming in The Cambridge Companion to Women's Writing in Britain, 1660-1789. See also McMurran, 84-87.

7. Oldfield was previously patron to Richard Savage, Haywood's intimate friend at that time (Oakleaf $35 \mathrm{nI})$.

8. See Bowers, "Collusive Resistance" (48-64) and Force or Fraud (228-37).

9. I am using the publication dates provided by Spedding (8I9-2I) rather than those on the title pages of Haywood's works. Those works published in the autumn (like the first volume of Memoirs, published in September 1725) were usually printed with the date of the following year on the title page.

IO. See Carnell, A Political Biography 15.

II. See Carnell, A Political Biography 226.

12. See Carnell, Partisan Politics I5I.

13. See Carnell, "Green," and Powell, "Parroting."

14. For a more thorough discussion of the politics of The Fortunate Foundlings, see Carnell, Partisan Politics $143-50$.

15. For a discussion of the politics of Jemmy and Jenny Jessamy, see Carnell, Partisan Politics 152-6I.

W O R K S C I T E D

Backscheider, Paula R. "The Shadow of an Author: Eliza Haywood." Eighteenth-Century Fiction II.I (1998): 79-IO2.

Ballaster, Ros. "A Gender of Opposition: Eliza Haywood's Scandal Fiction." Saxton and Bocchicchio. $143-67$.

- Seductive Forms: Women's Amatory Fiction from 1684-1740. Oxford: Clarendon Press, 1992.

Bannet, Eve Tavor, “'Secret history': Or, Talebearing Inside and Outside the Secretorie." The Uses of History in Early Modern England. Ed. Paulina Kewes. San Marino: Huntington Library, 2006. 367-88.

Barbauld, Anna Letitia. "On the Origin and Progress of Novel Writing." Anna Letitia Barbauld: Selected Poetry and Prose. Ed. William McCarthy and Elizabeth Kraft. Peterborough, Ontario: Broadview, 2002. 377-417.

[Boisguilbert, Pierre le Pesant.] Marie Stuart, Reyne D'Escosse. Nouvelle Historique. Paris: [L. Billaine], 1675. Microfilm.

Bowers, Toni. "Collusive Resistance: Sexual Agency and Partisan Politics in Love in Excess." Saxton and Bocchicchio. 48-68. 
Force or Fraud: British Seduction Stories and the Problem of Resistance, 1660-1760. Oxford: Oxford UP, 2011.

-. "Sex, Lies, and Invisibility: Amatory Fiction from the Restoration to MidCentury." The Columbia History of the British Novel. Ed. John Richetti, John Bender, Deidre David, and Michael Seidel. New York: Columbia UP, 1994. 48-68.

[Brémond, Sébastien.] Hattige, or, The Amours of the King of Tamaran. A Novel. Amsterdam: Simon the African [Richard Bentley], 1680. Early English Books Online. Web. July I. 2014.

Bullard, Rebecca. The Politics of Disclosure 1674-1725: Secret History Narratives. London: Pickering \& Chatto, 2009.

Carnell, Rachel. “It's Not Easy Being Green: Gender and Friendship in Eliza Haywood's Political Periodicals." Eighteenth-Century Studies 32.2 (1998-99): 199-214.

- Partisan Politics, Narrative Realism, and the Rise of the British Novel. Basingstoke and New York: Palgrave Macmillan, 2006.

- A Political Biography of Delarivier Manley. London: Pickering \& Chatto, 2008.

[Curll, Edmund.] An Impartial History of the Life, Character, Amours, Travels, and Transactions of Mr. John Barber. London: E. Curll, 174I. Eighteenth Century Collections Online. Web. July I, 20I4.

Davis, Lennard. Factual Fictions: the Origins of the English Novel. New York: Columbia UP, 1983.

Freebairn, James. The Life of Mary Stewart, Queen of Scotland and France. Written originally In French, and now done into English. Edinburgh, 1725. Eighteenth Century Collections Online. Web. July I, 2014.

The Fugitive Statesman, in Requital for The Perplex'd Prince. London: A. Grover, 1683. Early English Books Online. Web. July I. 2014.

Godenne, René. Preface. Hattigé, ou les Amours du Roy de Tamaran. Nouvelle. By [Sébastien Brémond]. 1676. Geneva: Slatkine. Reprints, 1980. vii-xii.

Grobe, E.P. "Gabriel and Sébastien Brémond." Romance Notes 4.2 (1963): 132-35.

Harris, Frances. A Passion for Government: The Life of Sarah, Duchess of Marlborough. Oxford: Clarendon P, 199I.

[Haywood, Eliza.] The Adventures of Eovaai, Princess of Ijaveo. A Pre-Adamitical History. 1736. Ed. Earla Wilputte. Peterborough, Ontario: Broadview, 2000.

[—.] The City Jilt; or the Alderman turn'd Beau: A Secret History. 2nd ed. London: J. Roberts, I726. Eighteenth Century Collections Online. Web. July I, 2014.

[- . The Fair Hebrew: or, a True, but Secret History of Two Jewish Ladies, Who Lately Resided in London. London: J. Brindley et al., 1729. Eighteenth Century Collections Online. Web. July I, 2014.

[—. The Fortunate Foundlings. London: T. Gardner, 1744. Eighteenth Century Collections Online. Web. July I, 20I4.

[—. The History of Jemmy and Jenny Jessamy. 3 vols. London: T. Gardner, 1752. Eighteenth Century Collections Online. Web. July I, 2014.

- The Injur'd Husband; or, the Mistaken Resentment. A Novel. London: D. Brown et al., 1722. Eighteenth Century Collections Online. Web. July I, 2014.

- The Invisible Spy. 3 vols. London: T. Gardner, 1754. Eighteenth Century Collections Online. Web. July I, 20I4.

[—..] A Letter from $\mathrm{H}-\mathrm{G}-\mathrm{g}$. ... to a Particular Friend. London, 1749. Eighteenth Century Collections Online. Web. July I, 2014. 
Love in Excess. 3 vols. London: W. Chetwood, 1719, 1720. Ed. David Oakleaf. 2nd ed. Peterborough, Ontario: Broadview Press, 2000.

- Mary Stuart, Queen of Scots: Being a Secret History of her Life. London: D. Brown et al., 1725. Eighteenth Century Collections Online. Web. July I, 2014.

[-.] Memoirs of a Certain Island Adjacent to the Kingdom of Utopia. 2 vols. London, 1724, 1725. Eighteenth Century Collections Online. Web. July I, 20I4.

[- . The Secret History of the Present Intrigues of the Court of Caramania. London, 1727. Eighteenth Century Collections Online. Web. July I, 2014.

Ingrassia, Catherine. Authorship, Commerce, and Gender in Early Eighteenth-Century England: A Culture of Paper Credit. Cambridge: Cambridge UP, 1998.

King, Kathryn. A Political Biography of Eliza Haywood. London: Pickering \& Chatto, 2012.

Kvande, Marta. "The Outsider Narrator in Eliza Haywood's Political Novels." SEL 43.3 (2003): 625-43.

The Life and Character of John Barber, Esq; late Lord-Mayor of London. London: T. Cooper, 1741. Eighteenth Century Collections Online. Web. July I, 2014.

Manley, Delarivier. The Selected Works of Delarivier Manley. Ed. Rachel Carnell and Ruth Herman. 5 vols. London: Pickering \& Chatto, 2005.

McMurran, Mary Helen. The Spread of Novels: Translation and Prose Fiction in the Eighteenth Century. Princeton: Princeton UP, 2010.

Oakleaf, David. Introduction. Love in Excess. By Eliza Haywood. Ed. David Oakleaf. 2nd ed. Peterborough, Ontario: Broadview Press, 2000.

Patterson, Annabel. Early Modern Liberalism. Cambridge: Cambridge UP, 1997.

Powell, Manushag N. "Parroting and the Periodical: Women's Speech, Haywood's Parrot, and Its Antecedents." Tulsa Studies in Women's Literature 27.I (2008): 63-9I.

[Procopius of Caesarea.] The debaucht court. Or, The lives of the Emperor Justinian and his Empress Theodora the comedian. Faithfully translated into English. London: R. Baldwyn, 1682. Early English Books Online. Web. July I, 2014.

Reeve, Clara. The Progress of Romance through Times, Countries, and Manners. Colchester: W. Keymer, 1785; facsimile reprint. New York: Garland, 1970.

[S., T.] The Perplex'd Prince. London: R. Allen, [1682]. Early English Books Online. Web. July I, 20I4.

Saxton, Kirsten T. and Rebecca P. Bocchicchio, eds. The Passionate Fictions of Eliza Haywood. Lexington: U of Kentucky P, 2000.

[Somers, John.] True Secret History of the Lives and Reigns of all the Kings and Queens of England. N.p., 1702. Eighteenth Century Collections Online. Web. July I, 2014.

Spedding, Patrick. A Bibliography of Eliza Haywood. London: Pickering \& Chatto, 2004.

Stewart, Carol. "Eliza Haywood's The Fortunate Foundlings: A Jacobite Novel." EighteenthCentury Life 37.I (2013): 5I-7I.

Watt, Ian. The Rise of the Novel: Studies in Defoe, Fielding, and Richardson. Berkeley and Los Angeles: $U$ of California P, 1957 .

Whicher, George F. The Life and Romances of Mrs. Eliza Haywood. New York: Columbia UP, 1915 .

Wilputte, Earla. "Parody in Eliza Haywood's A Letter from $H-G-g$, Esq." Eighteenth-Century Fiction 17.2 (2005): 207-30. Academic Search Complete. Web. July I, 2014 .

. "Room to Fable Upon': The History of Charles XII of Sweden in Eliza Haywood's The Fortunate Foundlings." The Eighteenth-Century Novel 2 (2002): 23-44. 